POLISH POLITICAL SCIENCE

VOL XL 2011

PL ISSN 0208-7375

\title{
HUMAN RIGHTS IN THE TEACHINGS AND PRACTICES OF BENEDICT XVI
}

\author{
by Małgorzata Zamojska
}

Joseph Ratzinger, chosen for the See of Peter 19 April 2005, after three years of papal ministry, may be, in my opinion, considered a worthy continuator of John Paul's II mission, the latter described as the Human Rights Pope due to his activities in the field.

The main goal of this essay is to analyze Benedict XVI's most characteristic practices and texts, which directly refer to the issue of human rights, especially in the context of respect for and protection of human rights. The next aim is to show the contexts in which John Paul II's great friend invokes or refers to the legacy of his eminent predecessor and to demonstrate the differences between John Paul II and Benedict XVI's perception of the significance of human rights in the lives of contemporary societies.

John Paul II is usually perceived as an ecumenist but also as the defender of human dignity. Father Maciej Zięba notices in his lecture that this subject is connected with the Pope's actions for human rights protection. In the following part of Fr Zięba's dissertation he suggests that "in European consciousness the issue of human rights is intertwined with the French Revolution, which opposed the postulates for respecting human rights to the Gospel and the Church. However, few would remember, Fr 
Zięba emphasises, that both Cracow Academy and Salamanca Academy, as well as Paul III in the mid $17^{\text {th }}$ century deliberated on the subject. Likewise, it was obvious for John Paul II that the Church must protect human rigths. The representative of the Anglo-Saxon world, sir Michael Howard asserts that the $20^{\text {th }}$ century witnessed two revolutions. One of them was the Bolshevik Revolution, and the second one was when the Roman Catholic Church became the biggest institutionalised human rights protector in the world. It was a shock for the Protestant world, since till then this community associated the Roman Catholic Church with intolerance, oppressiveness and feudalism. As a result of a change in the Protestant public perception of the Church, e.g. diplomatic relations with the Holy See were established [in John Paul II's time] by Sweden or the United States. As a consequence, the Holy See was recognised as a partner in the international talks on the human rights"1 [my emphasis - M.Z.].

The historical context and John Paul II's great achievement in the field of establishing a dialogue about human rights oblige Benedict XVI to take the responsibility for the worthy continuation of the Polish Pope's mission. As Fr Zięba's opinion confirms, the Catholic Church began this mission ages ago. Therefore neither John Paul II nor Benedict XVI can be perceived as the precursors in taking up this important subject. Still, thanks to their efforts the Vatican is not only a theoretical legislator but an equal partner in the human rights dialogue in the international arena.

Moreover, all the activities for the protection of individual human rights taken up by the head of the Church aim to, first of all, sensitize the faithful and raise their awareness of respect for human rights and the question of maintaining peace in the world. Secondly, they seek to assign to them, as Christians, the duty of absolute protection of those rights, i.e. the right to life (abortion ban), the right to freedom (in the negative sense, because neither John Paul II nor Benedict XVI condemn(ed) liberalism), the right to a dignified life.

1 The quoted statement of Fr Zięba constitutes a part of a lecture inaugurating the Polish Scientific Conference entitled John Paul II and Europe which took place 29 V 2008 and it was organised by the Political Science Institute of the Nicolaus Copernicus University in Toruń. 
Benedict XVI emphasises that the Universal Declaration of Human Rights of the United Nations from 1948, to which he directly refers in his numerous speeches and even in his publications, can be recognized as a model document which defines and interprets individual human rights in accordance with the Roman Catholic Church doctrine ${ }^{2}$. He stresses that "the Universal Declaration of Human Rights - signed by almost all countries of the world in 1948, after the terrible expierience of World War II fully expresses, even in its title, the awareness that human rights (including the fundamental right to life) naturally belong to man, and that the state recognizes these rights but it does not allot them. These rights belong to all the people as people and not on account of their secondary characteritics, which others would have the right to determine at their own descretion. It is understandable that if the state usurps the right to determine who deserves to have the rights and who does not, and if, as a consequence, it provides some with the legal validity to violate the fundamental right to life of others, it contradicts the idea of democracy [my emphasis - M.Z. ] it is constantly invoking and damaging the foundations it rests upon. By accepting the violation of the right of the weakest it also accepts the right of force over the force of the law." 3 Therefore, to successfully protect the right to life, an unequivocal abortion ban is needed. Every person requires moral respect and when there is a conflict of values, i.e. it is necessary to choose between the protection of an adult person's right to freedom and the protection of the conceived, the right to life should always win as fundamental and inalienable. As Benedict XVI adds: "no one denies that sometimes the decision to perform abortion is made in the face of a real and very dramatic situation. Nevetheless, taking advantage of this right [to freedom] is inextricably bound with the loss of life of an innocent human being, whose rights are not even considered. [...] the rights of some are created by the refusal of the fundamental right to life

2 Compare: J. Ratzinger, Europa Benedykta w kryzysie kultur, Częstochowa 2005, p. 83 Benedict XVI's address to the General Assembly of the United Nations Organization in New York given 5 May 2008: www.papiez.wiara.pl/?grupa=6\&art=1208554725\&dzi= $1175598824 \&$ katg $=$ [July 25, 2008].

3 J. Ratzinger, Europa Benedykta w kryzysie kultur, Częstochowa 2005, pp. 83-84. 
to others. Every legalisation of an abortion assumes the idea that it is the force that builds the law."

In the above reflections Benedict XVI is a worthy continuator of John Paul II's thoughts, especially from the point of view of maintaining the powerful concept of truth, which was turned into action by his predecessor. The existence of this powerful concept of truth is an answer to the contemporary relativism and to the attempts at justification that human rights depend on the culture or historical context. Benedict XVI, like John Paul II, rejects relativism. He writes in the context of the necessary protection of the right to life: "the recognition of the sacred character of the human life and its inviolability without any exceptions is not a minor problem or an issue that could be considered relative and subject to the plurality of opinions present in the contemporary society." ${ }^{5}$ Moreover, the protection of the conceived life is, according to the present Pope, "an essential condition for the social life worthy its name to be possible [my emphasis - M.Z. ]", 6 and the violation of the right to life results in a situation when people "inevitably lose their own identity."

The Pope's demand for the protection of the inborn human beings, the unequivocal abortion ban, the need to respect the fundamental, in his opinion, right to life of the weakest individuals in the society is not a histerical voice which we hear from the activists of the League of Polish Families. Benedict XVI's arguments have nothing in common with the ultracatholic press journalists' rhetoric ("Nasz Dziennik", "Gość Niedzielny"). Although the protection of the right to life is every Christian's duty, the writings of the present Pope lack the narrow-minded references to sin, punishment or the desire to condemn those to blame. Benedict XVI, faithful to John Paul II's powerful concept of truth, tactfully suggests that respect for a person, in accordance with the conclusions of the Catholic personalism, results in nothing less than a possibility of social life in general, i.e. a social life worthy the title 'social' in particular. It seems that here the present Pope suggests that altruism, i.e. the concern for oth-

\footnotetext{
4 Ibidem, pp. 82-82.

5 Ibidem, p. 78.

6 Ibidem.

7 Ibidem, p. 79.
} 
ers and for the protection of their fundamental rights makes people happy and active. The fact that people regard the right to life as more important than their individual freedoms builds the society. Without admission of this truth we would not deal with a society but with a set of atomized, separate, lonely individuals incapable of any interaction.

Benedict XVI's writings explicitly state that he recognizes the right to life as placed above other important human rights. At the same time the papal vision is not restricted to this conclusion, but it involves other numerous issues. It is worth emphasising that the Pope talked about human rights and the need to respect them during this year's pilgrimage to the United States, by which I mean the visit in the UN headquarters in New York, which took place May 5, 2008.

In his speech Benedict XVI stressed, above all, the special role of the $\mathrm{UN}$ in the human rights watch mission. Moreover, he evoked the figure of Francisco de Vittoria, a Dominican and the representative of the scholastic school from Salamanca, considered the father of the international law on account of the fact that statute law has significance only if it is rooted in the universal moral law, i.e. the natural law regulating the relations not only between single people, but also between nations (ius gentium). As he emphasised, the natural law experienced a renaissance in the $20^{\text {th }}$ century. The courts judged the Nazi war criminals and Christian politicians became the promoters of integration processes aiming at the international protection of ius gentium norms (the creation of the EU began).

It is worth emphasising, however, that the responsibility of protecting the natural law lies, in the first place, with the sovereign states. They are incapable of fulfilling this responsibility, when a gross violation of human dignity or a serious threat to peace and stabilisation of international order take place, or when a community represented by the UN for example has the right to intervene in accordance with the principle of subsidiarity. It is this global organisation that has the duty to carry out assignements or solve problems that are beyond the capabilities of the sovereign states.

In the further part of his speech the Holy Father refers to the aforementioned Universal Declaration of Human Rights from 1948, being a pecu- 
liar programme of the UN activity. The Pope, making use of the Declaration, attempted to present the appropriate vision of human rights. They cannot be, in his opinion, limited to a set of norms passed by the legislators and reduced to the level of a subjective legislative decision, or a projection entailed by an individual. Human rights, if they are to be obeyed, must involve the moral imperative of respect for human dignity, in accordance with the principle: do as you would be done by. The observance of human rights is a duty of every individual. The protection of the right to life, freedom and ownership is inextricably bound with the ban on killing or seizing other people's property and the moral obligation to love one's neighbour.

The Holy Father dedicated special attention, at the end, to the issues of interreligious dialogue and the important question of religious freedom. According to him, the religious freedom cannot be reduced to relativism. It should rather be treated as a challange to seek the truth.

It is worth noticing that this passage from the Pope's speech is addressed especially to the Muslims and the supporters of secularity. From the former he demands respect for freedom without which the acceptance of truth is worthless (Pope Innocent IV himself condemned converting by using force as pointless and offensive to God). Many Muslim countries seem to forget that human beings should enjoy religious freedom since only as free and rational subjects can they open to the work of grace and God's subjectivity can be recognized by all civilisations and cultures.

The supporters of secularity, on the other hand, were asked by the Pope to respect religion, which should have the right to influence public life. As he emphasised, the representatives of secularism decline religion this right, thus violating the genuine religious freedom.

Pointing out this contemporary problem the Pope proposed a completely different way of understanding religious freedom, which could involve the subjective character of a human being and his/her right to seek the truth, and also the possibility of preaching the truth. Religious freedom is solely the means of seeking the truth and expressing it in public. According to the Pope it is the UN that should guard religious freedom (in his understanding) and this freedom cannot be ideologised, which is commonly done by the heirs of the French Revolution and carried out by the 
lay states (such as France), which promote the aggressive principle of tolerance. $^{8}$

Benedict XVI referred to the issue of human rights (especially the right to life and religious freedom) in his message for the World Day of Peace on January 1, 2007. ${ }^{9}$ He supplemented his reflections in this context, strongly opposing all signs of discrimination; he wrote "inadequate consideration for the condition of women helps to create instability in the fabric of society. I think of the exploitation of women who are treated as objects, and of the many ways that a lack of respect is shown for their dignity; I also think - in a different context - of the mindset persisting in some cultures, where women are still firmly subordinated to the arbitrary decisions of men, with grave consequences for their personal dignity and for the exercise of their fundamental freedoms. There can be no illusion of a secure peace until these forms of discrimination are also overcome, since they harm the personal dignity given by the Creator to every human being."10

In the following part of his speech Benedict XVI underlines that "a true and stable peace presupposes respect for human rights. [...] Only if they are grounded in the objective requirements of the nature bestowed on man by the Creator, can the rights attributed to him be affirmed without fear of contradiction. [...] The recognition that there exist inalienable human rights connected to our common human nature has led to the establishment of the body of international humanitarian law which States are committed to respect, even in the case of war. [...] War always represents a failure for the international community and a grave loss for humanity. When, despite every effort, war does break out, at least the essential

8 Compare: a summary of Benedict XVI's address to the General Assembly of the United Nations Organization in New York given 5 May 2008: www.opusdei.pl/art. php?p=27635 [refresh: 25 VII 2008, time: 19:10]; full text of the Pope's speech: www. papiez.wiara.pl/?grupa $=6 \&$ art $=1208554725 \& \mathrm{dzi}=1175598824 \&$ katg $=[$ July 25,2008$]$.

9 Compare: www.vatican.va/holy_father/benedict_xvi/messages/peace/documents/ hf_ben-xvi_mes_20061208_xl-world-day-peace_pl.html [July 25, 2008.

10 Ibidem. 
principles of humanity and the basic values of all civil coexistence must be safeguarded; norms of conduct, that limit the damage and help to alleviate the suffering of civilians and of all the victims of conflicts, must be established." 11

The Pope in his speech, apart from direct references to the issue of human rights, alluded as well to the current problems requiring solutions on the international level, such as fighting the modern manifestations of terror, the need to reduce nuclear arms stockpile and the demand for the prevention of energy shortage.

The speech and visit in the Auschwitz-Birkenau camp during the pilgrimage to Poland in 2006 proved that Benedict XVI's reflection on the issue of human rights is not merely theoretical. The Pope emphasized the positive phenomenon of the former concentration camp and the area of Oświęcim as becoming places of numerous civil initiatives. At the same time, he stressed, with a dose of helplessness, that "to speak in this place of horror, in this place, where unprecedented mass crimes were committed against God and man, is almost impossible - and it is particularly difficult and troubling for a Christian, for a Pope from Germany. In a place like this, words fail; in the end, there can only be a deadly silence - silence which is itself a heartfelt cry to God: why, Lord, did you remain silent? How could you tolerate all this? In silence, then, we bow our heads before the endless line of those who suffered and were put to death here; yet our silence becomes in turn a plea for forgiveness and reconciliation, a plea to the God never to let this happen again."12

Perhaps Benedict XVI's concept - the recognition of the important role of human rights in the life of the individual and the whole society - is to prevent similar tragedies, in the face of which one can only be quiet?

The Pope not only guards the observance of human rights but he also evocatively encourages all the Christians who want to actively participate in the social life to do it. Moreover, an important place in his coherent vision is designated to the United Nations, which "set the fundamental

\footnotetext{
11 Ibidem.

12 Benedict XVI's speech during the visit in Poland in the Auschwitz-Birkenau camp, 28 May 2006: www.vatican.va/holy_father/benedict_xvi/speeches/2006/may/documents/ hf_ben-xvi_spe_20060528_auschwitz-birkenau_en.html [July 25, 2008].
} 
task to promote the human rights indicated in the 1948 Universal Declaration. That Declaration is regarded as a sort of moral commitment assumed by all mankind. There is a profound truth to this, especially if the rights described in the Declaration are held to be based not simply on the decisions of the assembly that approved them, but on man's very nature and his inalienable dignity as a person created by God. Consequently, it is important for the international agencies not to lose sight of the natural foundation of human rights. This would enable them to avoid the risk of sliding towards a merely positive interpretation of those rights. If this happened, the international bodies would lack the necessary authority to carry out their role as defenders of the fundamental rights of the people, the chief justification for their very existence and activity" [with reference to this issue the Catechism of the Catholic Church specifies strict and precise criteria: $\mathrm{cf}$. 2307-2317]..$^{13}$

In the context of the foregoing reflections one can advance a thesis that the actions and teachings of Benedict XVI constitute a specific commentary on the Universal Declaration of Human Rights of December 1948, because its preamble states that:

1. recognition of the inherent dignity and of the equal and inalienable rights of all members of the human family is the foundation of freedom, justice and peace in the world;

2. disregard and contempt [for these values] have resulted in barbarous acts which have outraged the conscience of mankind;

3. strive to build such a world in which people could enjoy the freedom of speech and belief, and the freedom from fear has been proclaimed as the highest aspiration of the common people;

4. it is necessary to determine human rights by the rule of law;

5. a common understanding of these rights and freedoms is of the greatest importance for the full realisation of this pledge;

\footnotetext{
13 Compare: www.vatican.va/holy_father/benedict_xvi/messages/peace/documents/ hf_ben-xvi_mes_20061208_xl-world-day-peace_pl.html [July 25, 2008].
} 
6. it is essential to promote the development of friendly relations between nations and the unanimous aspiration for realisation of the declaration;

7. the observance of the articles of the Universal Declaration of Human Rights is considered the ultimate goal of every individual and every nation.

What can pass for such a commentary to the extract from the preamble of the Universal Declaration of Human Rights is both the frequent emphasis on the subjectivity of man by Benedict XVI and the demand for respect towards his self. Moreover, in the afore-cited papal message for World Peace Day of January 1, 2007 it is stated: "many tensions jeopardizing the peace are undoubtedly caused by numerous unjust inequalities, which are still a tragedy in the world. Among these, the most insidious are, on the one hand, inequalities in access to basic goods, such as food, water, home, health care; on the other hand-sustaining inequalities between men and women in enforcing fundamental human rights. The recognition of basic human equality, which results from common transcendental dignity, constitutes an extremely important part of building peace. Equality at this level is therefore a common good, inscribed in the natural "grammar" that can be read from the divine intention of creation; the good that cannot ignore or neglect that "grammar," otherwise it could cause a serious threat to peace. The extremely grave deprivation afflicting many peoples, especially in Africa, lies at the root of violent reactions and thus inflicts a terrible wound on peace."14

In turn, a similarly literal reference to the second part of the aforementioned preamble, is the above-cited speech given during the visit to Auschwitz-Birkenau.

Similarly, the declaration's postulate regarding the need to build a world "in which people could enjoy freedom of speech and belief, and freedom from fear and want," immediately brings to mind Benedict XVI's conception of religious freedom, so different from the presented conception; is

\footnotetext{
14 Compare: ibidem.
} 
religious freedom, in this context, not understood by the Pope as the freedom of speech, the right to public stating one's religious belief without violating others' freedom, i.e. without the need to condemn them to the suffering of "fear and want"?

It is also obvious for Benedict XVI that "it is necessary to determine human rights by the rule of law and to commonly understand these rules and freedoms." Law should be made on the basis of neotomistic personalism, rather than positivistic individualism, which he puts in his speech at the UN General Assembly. The key to a common understanding of these already made - laws is made by subjectivity of human individual, which category is - according to him - universal and commonly understood. Thus, all these reservations expressed both in the preamble to the declaration and in papal papers have huge significance for complete realisation of the above-stated goals. However, they will not suffice unless we aid the processes of establishing friendly relations among nations and support their unanimous aspiration for realisation of the declaration, whose observance is unanimously considered to be the ultimate goal of every individual and every nation.

As it can be seen in the foregoing reflections, realisation of the Universal Declaration of Human Rights is important not only to individual countries as subjects in the international politics; not only for communities that those countries managed to establish among themselves; it is also important for the head of the Catholic Church. One can therefore say with all responsibility that he has found teological basis and substantiation for the matter of the secular document, which makes his teachings modern, versatile and very much involved in recent social and political problems, which he strives to solve in an honest and at the same time attractive way to contemporary man.

The contemporary man is the focus of his attention. We can clearly see that Benedict XVI follows in John Paul II's footsteps, often referring to the legacy of his predecessor for substantiating particular theses of his own teachings. However, after three years of his pontificate one may state that the issue of human rights - one of numerous issues among diverse teachings of the Polish Pope -is the main concern of Benedict XVI; while reading his papers one may have the impression that although the Pope 
touches upon several matters, he almost always tries to refer to at least one of the threads of the concept presented in this essay. ${ }^{15}$

It seems that the concern to spread his vision results from the awareness that human rights are being violated, even in the Christian world. Therefore, contemporary society is regarded by Benedict XVI as the biblical prodigal son who, having erred and blundered, eventually comes back to the bosom of his family and is welcomed by the forgiving father. ${ }^{16}$ Contemporary world, which, according to the Pope, is in the state of crisis, has forgotten about the necessity of respecting human rights, and betrayed not only the Ten Commandments, but also does not hestiate to violate the statute law. Contemporary world errs, but Benedict XVI - like the good father from the evangelical parable - does not turn his back on it, but accepts it the way it is. Benedict XVI' mission is therefore to wait patiently for an opportunity to realise the vision of common respect for human rights across the world.

Is it possible for such a vision to come true? I think that Benedict XVI is deeply convinced of that, because in his opinion respect for human rights is not only a Christian duty, but it is also supposed to be "giving a human answer to the love of God" in a wider context. ${ }^{17}$

As he states in the further part of his first encyclical, describing the role of the Church in respecting human rights "a fair order of society and state is a central goal for politics. A state that was not guided by justice, would be reduced to a big pack of thieves [...]." And he adds, referring to the issue of the role of the state and the Church in society, "the state must not impose religion. It must guarantee the freedom of religion and peace among adherents of different religions; the Church as a social expression of the Christian faith, from its position has its independence and on the basis of faith exists in a form of community that should be respected by

15 See: particular messages of Benedict XVI for the World Peace Day (January 1, 2007): www.vatican.va.

${ }^{16}$ Benedict XVI, Jezus $z$ Nazaretu. Od chrztu $w$ Jordanie do Przemienienia, part 1, Kraków 2007, pp. 174-181.

17 ibidem, the Encyclical Deus caritas est: www.vatican.va/holy_father/benedict_xvi/ encyclicals/documents/hf_ben-xvi_enc_20051225_deus-caritas-est_pl.html [July 25, 2008]. 
the state. Both realms are separated, but they always remain in mutual relation. ${ }^{18}$

This mutual relation is necessary, because the goal of any country's politics is justice. Still, regardless of historical and cultural contexts, politicians have always been helpless with the following questions: "how to realize justice here and now?", and another, more radical one coming along: "what is justice?"19 This is where, as Benedict XVI claims, politics and faith meet; faith helps the human mind discern what is just. Thus, it also helps in the realisation of a clearly-defined main goal of state's politics. It is worth mentioning that the Church - according to the Pope - is not supposed to directly participate in the rule, or "impose on those who do not share the faith, the views and manners of behaviour that belong to it." 20

The Pope believes that the mission that he entrusts to the Church is not political, but it is supposed to serve the humanity. Therefore, he suggests that the Church should neither take the place of the state, nor take up political fight, still it cannot "stay on the margin of the fight for justice."21 It is obliged to do so-called service of love (caritas), which is necessary even in the most just society, because there will always be somebody else beside us. There will always be suffering, as Benedict XVI writes, that will need soothing. There will always be loneliness. There will always be situations of material need, in which it is necessary to help in the spirit of real love of neighbour. ${ }^{22}$

A state that tries to handle every problem at any cost eventually becomes a bureaucratic machine. Thus, "we do not need a state that establishes and controls everything, but a state that supports, in the spirit of subsidiarity, the initiatives undertaken by various social forces, combining spontaneity with closeness to people seeking help."23

For centuries, the Church has been realising the above-mentioned goals by means of various charity actions. However, the material kind of support

\footnotetext{
18 Ibidem

19 Ibidem

20 Ibidem.

21 Ibidem.

22 Ibidem.

23 Ibidem.
} 
that it has been providing, is not the only one. It also gives spiritual support. Thanks to this, the Church, without engaging directly in politics, serves "for a just organisation of state and society."

Therefore, shaping of just structures is not a direct goal of the Church. The aim of the Church in this area is indirect, as it consists in helping to build up just social structures. Whereas, as Benedict XVI claims, the direct action for a just social order is a domain of the lay faithful. They are called to participate in public life in person as the citizens. [...] The mission of the lay faithful is therefore to shape a proper social life, respect its authorized autonomy and co-operate with other citizens, according to their competence and responsibility. Although specific expressions of the ecclesiastical caritas cannot interfere in the actions of the state, it is nevertheless true that it should stimulate the entire existence of the lay faithful, which also includes their political activeness, treated as social charity. ${ }^{24}$

To sum up, it is necessary to point the main elements of the concept of human rights, which can be distinguished after three years of the pontificate of Benedict XVI. Firstly, in this context one can notice a surprising fact that the matter of human rights is, so far, the central issue of papal teachings, around which a further papal reflection is being organised.

Secondly, this reflection draws from the legacy of John Paul II, especially in the area of using the powerful concept of truth and the priority of protection of human dignity. Still, Benedict XVI enriches his dialogue on human rights with secular elements, by using, for example, the Universal Declaration of Human Rights of 1948 for teological reflection. This contributes to the making of the discussion on human rights less hermetic and becoming a general social discourse, which must concern all people, not only Catholics.

Thirdly, Benedict XVI enriches the discussion on human rights with a convincing, in my opinion, definition of religious freedom, which has a lot to do with the freedom of speech and belief. Besides, the Pope is a strong opponent of any manifestations of discrimination, especially

\footnotetext{
24 Ibidem.
} 
sexual, nevertheless holding the position that the right to life is the fundamental right of every human being. Therefore, if we are to deal with a conflict of two values, for example the right to life and the individual freedom, everybody is obliged to protect life at a cost of curtailing their freedom. This means that the Pope is a tenacious opponent of abortion. However, the justification of this ban is rational, almost commonsensical. Therefore, it has nothing to do with ultracatholic propaganda that always rages during parliamentary discussions on conditions rendering abortion or euthanasia acceptable.

In conclusion, it is necessary to underline that it is very important for Benedict XVI that every individual, not only Christians, should consider respecting human rights their duty. Therefore, observance of human rights is for Benedict XVI a foundation upon which one can build a just and modern society. 